\title{
Needs Analysis for ESP Course Development: Thai Civil Engineering Students' Perspectives
}

\author{
Benjaporn Thepseenu \\ School of Liberal Arts, University of Phayao, Thailand. \\ Email:benjaporn.th@up.ac.th Tel:66918548425
}

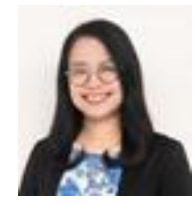

\begin{abstract}
This study aimed to investigate civil engineering students' English language learning needs and perceptions of their English for Specific Purposes (ESP) course based on the past students' perspectives (Brown, 2016). The study sample comprised 85 third-year Thai students, majoring in civil engineering at University of Phayao, Thailand in the academic year 2018. A mixed-methods research design was employed. A questionnaire on civil engineering students' needs for ESP course was used to investigate the students' perceived needs on their ESP course. Subsequently, a focus group interview was conducted to explore the students' overall perceptions of the ESP course they had finished. Data from the questionnaire were analyzed by means of frequency, mean, and standard deviation. Interview data were analyzed using content analysis. The findings revealed students' high demand of communicative topics particularly speaking and listening in work-related situations. A combination of pair and group work for in-class activities and out-ofclass assignments was preferred over working individually. A mixture of Thai and English as a language of instruction was also needed. Pedagogical implications for ESP course designers and teachers of other fields of engineering are put forward to highlight the crucial role of needs analysis in ESP course development.
\end{abstract}

Keywords: Needs analysis, English for specific purposes (ESP), Civil engineering students' perspectives, Classroom-learning analysis, English language needs, ESP course development.

Citation | Benjaporn Thepseenu (2020). Needs Analysis for ESP Perspectives. Asian Journal of Civil Engineering Students

442.
History:

Received: 13 April 2020

Revised: 18 May 2020

Accepted: 19 June 2020

Published: 25 June 2020

Licensed: This work is licensed under a Creative Commons

Attribution 3.0 License (cc)

Publisher: Asian Online Journal Publishing Group
Funding: The research was supported by School of Liberal Arts, University of Phayao, Thailand.

Competing Interests: The author declares that there are no conflicts of

interests regarding the publication of this paper.
Transparency: The author confirms that the manuscript is an honest, Transparency: The author confirms that the manuscript is an honest,
accurate, and transparent account of the study was reported; that no vital features of the study have been omitted; and that any discrepancies from the study as planned have been explained.

Ethical: This study follows all ethical practices during writing.

\section{Contents}

1. Introduction

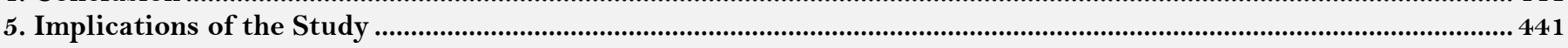

6. Limitations of the Study and Suggestion for Future Research ..................................................................................441

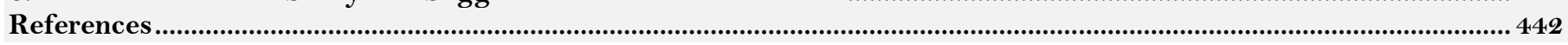




\section{Contribution of this paper to the literature}

This study contributes to the existing literature by exploring civil engineering students' needs for their English for Specific Purposes course in terms of course content, specific language skills in work-related situations as well as learning and teaching activities.

\section{Introduction}

In the field of teaching English for Specific Purposes (ESP), the notion of analyzing learners' needs or needs analysis (NA) has been perceived as an important component of course design (Brown, 2016). NA is regarded as an essential step in curriculum development with the main aim of identifying "what learners will be required to do with the foreign language in the target situation and how learners might best master the target language during the period of training" West (1994) cited in Kim (2013). Flowerdew (2013) notes that NA was first introduced into ESP field in the 1970s and has been "evolving and refining itself" since then (p. 326). She also points out that NA "is the first stage in ESP course development, followed by curriculum design, material selection, methodology, assessment, and evaluation" (p. 325). According to Hyland (2006) cited in Flowerdew (2013), NA can be broadly defined as follows:

Needs analysis refers to the techniques for collecting and assessing information relevant to course design; it is the means of establishing the how and what of a course. It is a continuous process, since we modify our teaching as we come to learn more about our students, and in this way it is actually shades into evaluation- the means of establishing effectiveness of a course. Needs is actually an umbrella term that embraces many aspects, incorporating learners' goals and backgrounds, their language proficiencies, their reasons for taking the course, their teaching and learning preferences, and the situation they will need to communicate in. Needs can include what learners know, don't know or want to know, and can be collected and analyzed in a variety of ways. (p. 324)

Exploring learners' reasons for taking an English language class and their learning preferences can help teachers improve their teaching (Scrivener, 2005). Therefore, conducting NA before designing syllabus can provide useful information for teachers to make decision about what should be included in the course based on learners' specific needs instead of teachers' intuitions or preferences only (Gözüyeşil, 2014).

\subsection{Defining English for Specific Purposes and Needs Analysis}

Byram and $\mathrm{Hu}$ (2017) define ESP as:

The term 'English for Specific Purposes' (ESP) is used to refer to the teaching and learning of English for work or study-related purposes. ESP courses are based on an analysis of learners' needs in relation to the learners' target discipline, workplace or profession. They aim to help learners enter or progress in their chosen disciplines and fields. As ESP course focus on languages and skills of direct relevance to the learners' real-world needs, they function as efficient means by which learners can reach their language learning goal. (p. 223)

Byram and $\mathrm{Hu}$ (2017) describe a vital role of NA for ESP course development that: "[A]ssessing needs and describing language use in the specific field are two important elements in ESP course development. The assessment of needs indicates what should be included as course content. Description of language use provide information about communication in the target work area or discipline and provide language content for the course" (pp. 223-224). They also added that "[N]eeds analysis is critical to the planning of an ESP course. Needs analyses are conducted before a course begins to help course developers select course content, decide the level of proficiency at which to pitch the course and required exit levels. Needs analyses are also conducted during a course for the purpose of find-tuning the course content" (p.224). This suggests that NA is essential to be conducted in ESP courses in order to identify learners' specific needs and select language contents that meet their needs. In addressing teaching ESP, a teacher is a key person who is expected to develop an English language course that best suits learners' needs which is highlighted in the above definition. Needs of the prospective learners is, therefore, closely linked to a way an ESP course will be designed to serve specific learning goals for students in a specific discipline

Based on a dictionary, ESP is defined as "the role of English in a language course or programme of instruction in which the content and aims of the course are fixed by the specific needs if a particular group of learners" (Richards \& Schmidt, 2010, as cited in Brown (2016)). Looking at this definition, Brown (2016) concludes that "if there is no needs analysis, there is no ESP" and suggested that "NA and ESP are intricably intertwined" (p. 5). This indicate that NA should not be neglected in ESP course development.

According to Brown. (1995), NA refers to "the systemic collection and analysis of all subjective and objective information necessary to define and validate defensible curriculum purposes that satisfy the language learning requirements of students within the context of particular institutions that influence the language learning and teaching situation" (Brown. (1995), as cited in Brown (2016)). Thus, NA can inform people involved about required aspects in the process of course development.

Brown (2016) further explains that such definition relates to three concepts of stakeholder, a defensible curriculum, and necessary information. Hence, in order to conduct an NA, people in charge of assessing learners' needs referred 
to as "the needs analyst(s)" should consider the aforementioned elements of NA as much as possible to ensure a successful ESP course (Brown, 2016). In addition, the need analyst(s) should have a clear understanding of how they are going assess needs at the initial stage of course development as there are different views which are: "(a) the democratic view: whatever the most people want, (b) discrepancy view: whatever is missing, (c) analytic view: whatever logically comes next, and (d) diagnostic view: whatever will do most harm if missing" (Brown, 2016). In the context of the present study, a democratic view of needs or "whatever the most people want" (Brown, 2016) was taken and classroom-learning analyses which "investigate what the classroom learning situation is or should be" (Brown, 2016) was used to explore needs on the part of learners. Learners in the present study had already taken an ESP course and it was expected that their perspectives on classroom-learning experience would be beneficial in other ESP course development.

\subsection{Methods for Collecting ESP NA Data}

NA information can be gathered with different stakeholder groups using different methods of data collections. According to Long (2005) as cited in Lung (2014) NA methods include the followings.

Surveys may be conducted, interviews engaged in and non-expert intuitions as well as expert intuitions brought into play. At the same time, language audits, participant and non-participant observations, diaries, journals and logs may also be formulated. Finally, content analysis, register analysis, computer-aided corpus analysis and triangulation analysis all share in arriving at a needs analysis.

Brown (2016) suggests the use of mixed-methods research or "MMR" in NA. In terms of gathering data, Brown (2016) also suggests the use of interviews with teachers and learners, classroom observation, questionnaires, and written ESP corpus.

\subsection{Studies on ESP NA}

Needs analysis in ESP has been extensively studied. The common goal of such studies is to gain insights into needs, wants, and expectations of stakeholders in order to design an ESP syllabus or to adjust teaching and learning activities according to the reported needs. Data for needs analyses can be obtained through various sources as suggested by Long (2005) cited in Flowerdew (2013): "published and unpublished literature, learners, teachers and applied linguists, domain experts, and triangulated sources." In terms of methods, Long (2005) suggested to use "expert intuitions, participant and non-participant observation, ... unstructured interviews, ... surveys and questionnaires, structured interviews, and less commonly, criterion-referenced performance tests" (cited in Flowerdew (2013)). Examples of research investigating needs in ESP carried out in different fields of study including engineering are as follows.

Dehnad, Bagherzadeh, Bigdeli, Hatami, and Hosseini (2014) investigated reading and writing needs of 56 postgraduate students at the School of Health Management and Information Sciences of Iran University of Medical Sciences, 5 ESP teachers, 5 heads of departments and 1 executive manager at the Ministry of Health in Iran through questionnaire survey and semi-structured interviews. The results revealed that students needed reading and writing skills for their study and work. Reading technical texts was perceived by $68.5 \%$ of them as an important reading skill they needed for their study, and reading technical journals was needed by the majority of them in their work time. As for writing skills, the majority of students viewed that electronic letter writing in English was needed in both study and work settings. However, a mismatch among students' needs and other stakeholders was found. Thus, the researchers called for needs analysis with all groups of stakeholders for designing a new ESP syllabus for postgraduate students in this university. Other researchers, such as Aliakbari and Boghayeri (2014) investigated English language needs of 49 architecture students and 72 architecture graduates at Ilam University in Iran by using questionnaires. The study reported what the participants expected from the ESP course provided by the university. It was found that both groups of participants considered reading as the most important skill, followed by writing, speaking, and listening respectively. A need for revising the existing ESP course for architecture students was suggested as the overall findings showed that the course did not meet students' actual needs.

With regard to engineering fields, Kim (2013) used survey questionnaire to examine needs of 99 engineering students and 30 engineering teachers in a Korean university as compared to 43 Korean engineering major industry workers. The findings could provide information for course planners about specific English skills and contents perceived as the most important by different groups of participants. There were both agreements and discrepancies among students' perceptions, their professors and industry workers. For instance, students thought English for daily conversations was the most important content for them, whereas engineering teachers and industry workers chose engineering contents and general business English, respectively. However, engineering teachers and industry workers shared the same view that speaking ability of their students and staff was the least satisfactory among other skills, and English language course for engineering was required. Hence, it was suggested that ESP teachers should include "ample portion on speaking" (Kim, 2013). In addition, students should recognize which English skills their teachers and industry workers expect them to master in order to prepare themselves to meet the requirements of the job market. 
Another study was reported by Gözüyeşil (2014). She carried out a needs analysis at Nigde University in Turkey with 133 engineering students, 246 prep class students, and 11 academics working at engineering faculty of this university to examine which English skills: reading, writing, speaking and listening was needed most for the engineering departments of the university. Two different questionnaires were used with different groups of students and semi-structured interviews were conducted with the academics to collect data. The results showed that reading was perceived as the most important skill which suggests that the language teachers at the prep school should focus more on developing reading skill. She concluded that "[T]he prep program used as a bridge by students in order to pass to the content area courses can be strengthened only by considering the requirements of departments and by reorganizing the curriculum according to the specific needs of departments” (Gözüyeşil, 2014).

With regard to NA studies in Thai context, Kaewpet (2009) qualitative study entitled "Communication needs of Thai civil engineering students" provides insights into communication needs of twenty-five stakeholders including civil engineering students and lecturers, employers, engineers, ex-civil engineering students of a technical English course, and ESP teachers. Through semi-structured interview with those people involved, four communicative events they thought to be necessarily included in an ESP course are "talking about daily tasks and duties, reading textbooks, reading manuals, and writing periodic/progress reports” (p. 266). This study also identified a list of communicative events that civil engineers are likely to encounter in their real workplace. Thus, the findings can guide ESP course developers for to make decision on course content and materials in the local and wider contexts

Another study was conducted in Thai context by Changpueng and Pattanapichet (2015). Though questionnaires and semi-structured interviews, they examined the needs for English writing skills in workplace of 110 managerial and operational engineers, 31 ESP teachers, and 354 engineering students from different departments (electrical, civil, mechanic, industrial, chemical, and productive). The results provided information on specific aspects of English writing skills required by managerial and operational engineers. Although a mismatch among the participants' points of view was found in some aspects, the analysis showed that all groups of participants had similar view on the types of genres that are important for engineers in the work environment such as enquiry e-mails and reports. Suggestions for using results from the analysis were offered for course designers and teachers to design effective ESP course for engineers

In conclusion, needs analyses have been investigated by many researchers around the world. Results from many studies highlight the important role of needs analysis in the process of course development.

Regarding the context of University of Phayao, ESP courses are offered for all fields of engineering including civil engineering. Undergraduate civil engineering students are required to take this course in the second semester of their third year of study. However, an NA has not been systematically carried out with civil engineering students to discover their English language needs. Therefore, it is the purpose of this study to conduct an NA with these students in order to develop effective ESP syllabus that best meets students' needs in the period of taking the course. Findings from the study would lead ESP teachers to develop appropriate teaching materials and select teaching approaches that meet students' wishes, knowledge, and language proficiencies. It is also hoped that when a language course is designed in accordance with what learners consider meaningful and appropriate for them, they would see its values and be more motivated to learn.

This study aimed to investigate civil engineering students' English language learning needs and perceptions of the course 146200 English for Specific Purposes. Research questions were generated as follows:

1. What English language skills and topics do the students perceive as necessary for an ESP course for civil engineering students?

2. What features of learning and teaching activities do the students prefer for an ESP course?

3. What are the students' perceptions of the ESP course they had taken?

The study focused on English language needs of the aforementioned participants in University of Phayao for the development of ESP course for civil engineering students who enrolled in 146200 English for Specific Purposes which is offered in the second semester in the third year of their study in a four-year degree program. Thus, aspects concerning students' perceptions of desired content, materials, language skills, and learning activities were investigated based on the perspectives of students who had taken such course which can be referred to as "the past students' perspectives" using classroom-learning analyses strategy suggested by Brown (2016).

\section{Methods}

\subsection{Research Design}

In order to analyze students' needs, a mixed-methods research design was employed. The quantitative component is predominant, with additional qualitative measures. The quantitative component of this study involves methods of collecting numerical data using an ESP NA questionnaire for civil engineering students. As for the qualitative method, a focus group interview was carried out to gain insights into students' perceptions of their experiences and needs in learning English for civil engineering purpose.

\subsection{Participants}

The participants of this study comprised 85 third-year undergraduate civil engineering students, School of Engineering, University of Phayao, Thailand. At the time of data collection, the students were in the second 
semester of the academic year 2017. They were L1 Thai learners of English as a foreign language. They enrolled in the course 146200 English for Specific Purposes in that semester as a compulsory course for their degree program. The group of participants consisted of 14 females and 71 males. Their ages ranged from 21 to 23 years. The average age was 21.4 years $($ mean $=21.40)$.

\subsection{Research Instruments}

\subsubsection{A Civil Engineering Students' Needs for ESP Course Questionnaire}

A civil engineering students' needs for ESP course questionnaire consisting of 3 parts with 32 items, was designed by the researcher and used to gather demographic information about the students and their English language needs for an ESP course for civil engineering students.

Part 1 of the questionnaire was designed to obtain students' information about their ages and genders. It also included items about students' self-rated English proficiency in particular skills, namely, listening, reading, writing, speaking, vocabulary, and grammar. In addition, questions were designed to discover the students' opinions about the most needed skills for improving their English, their views on the importance of having ability in English for professional practice in civil engineering field, and potential purposes of using English in the future. This information would be useful for analyzing students' perceptions of these aspects which might explain their needs in learning an ESP course.

Part 2 of the questionnaire was aimed at gathering information about students' perceived needs for the contents that should be incorporated into the course. This part contained 20 items, representing topics students wanted to learn in an ESP course for civil engineering students. Most of the topics were both adopted and adapted from Kaewpet (2009) list of communicative events which "Thai civil engineers and/or Thai civil engineering students are likely to perform" (p. 268) in her interview schedules. Students were asked to rate the degree to which they needed to learn those listed topics on a five-point Likert-scale ranged from 1 (least) through 5 (most).

Part 3 of the questionnaire was created to gain students' views on patterns of classroom learning and teaching activities which include 6 statements: 1) Classroom activities should be done in pairs or groups; 2) Classroom activities should be done individually; 3) Out-of-class assignments be done in pairs or groups; 4) Out-of-class assignments be done individually only; 5) Teachers should use only English for instruction; and 6) Teachers should use both Thai and English for instruction.

Students were asked to indicate the extent to which they agreed or disagreed with those listed statements on a five-point Likert-scale ranged from 1 (strongly disagree) through 5 (strongly agree). Students were also encouraged to write down additional topics they thought should be incorporated into the course and other features of learning and teaching activities that were not listed in the questionnaire. They were not timed while completing the questionnaire.

\subsubsection{Focus Group Interview Guide}

A focus group interview was employed in order to explore students' needs in more depth at one time as pointed out by Dörnyei (2007) that "[T]his obviously an economical way to gather a relatively large amount of qualitative data" (p. 144). The interview data could complement data on students' needs obtained from the questionnaire. Thus, an interview guided with a list of questions was prepared. There was a list of interview questions which were either taken directly or slightly adapted from Brown (2016) suggested questions for meeting with students (p. 107). For example:

- Do you think you will use English for your work in the future? For what?

- What do you think about your experience in learning the ESP course this semester?

- And what are the topics that should be included in the course? Why do you think so?

- What improvement can be made to the ESP course?

\subsection{Data Collection}

Data collection took place in May 2018 after the end of the course 146200 English for Specific Purposes. The researcher, who had a role of a need analyst, course developer and instructor of the course, had a meeting with participants in their ESP classroom in order to ask 94 students to participate in the research project. The researcher informed them of the purposes and significance of the study and obtained their written consent to participate in the study, prior to collecting data. A total of 85 students agreed to participate in the study.

Next, the researcher administered the questionnaire to 85 students. They completed the questionnaire within 15 minutes. One hour after administering the questionnaire, the researcher conducted a focus group interview with 7 students who volunteered to participate. In order to protect the students' identities, they were referred to as 'S' followed by a number. Henceforth, they were designated as S1, S2, S3, S4, S5, S6, and S7. The group consisted of 3 females and 4 males. The interview was conducted in Thai in a quiet office room and audio-recorded. The interview took 40 minutes. Finally, data gained from the questionnaire and the interview were then analyzed and presented to identify the students' needs for ESP course. 


\subsection{Data Analysis}

Responses to the civil engineering students' needs for ESP course questionnaire were scored as follows.

In part 2 of the questionnaire, responses were scored as: Least $=1$; Less $=2$; Moderate $=3$; Much $=4$; and Most $=5$.

Thus, high scores indicated a high degree of needs for particular topics. The mean scores were interpreted as follows.

$$
\begin{aligned}
& 4.51-5.00=\text { Most } \\
& 3.51-4.50=\text { Much } \\
& 2.51-3.50=\text { Moderate } \\
& 1.51-2.50=\text { Less } \\
& 1.00-1.50=\text { Least }
\end{aligned}
$$

In part 3 of the questionnaire, responses were scored as: Strongly disagree $=1$; Disagree $=2$; Moderately agree $=3$; Agree $=4$; Strongly agree $=5$. Thus, high scores indicated a strong agreement with the statements . Interpretation of range of mean scores was as follows.

$$
\begin{aligned}
& 4.51-5.00=\text { Strongly agree } \\
& 3.51-4.50=\text { Agree } \\
& 2.51-3.50=\text { Moderately agree } \\
& 1.51-2.50=\text { Disagree } \\
& 1.00-1.50=\text { Strongly disagree }
\end{aligned}
$$

Descriptive analysis was conducted using SPSS version 20. Descriptive statistics were generated in order to report students' degree of needs for course contents and agreements with the patterns of learning and teaching activities.

Participants' interview data was transcribed verbatim in Thai language. The transcripts were then coded and content-analyzed in order to find evidence of students' needs for ESP course, their opinions towards their experiences of learning English for civil engineering purpose and improvement of the future course. The researcher was also open to finding other related themes that emerged from the data and could be added to the existing themes to gain new insights.

\section{Results and Discussion}

\subsection{Results from the Questionnaire}

With regard to participants' perceptions of their proficiency in specific English language skills, namely, listening, reading, writing, speaking, vocabulary, and grammar, most of the participants rated their proficiency in each skill as fair $(49.4 \%, 58.5 \%, 41.2 \%, 37.6 \%, 47.1 \%$, and $47.4 \%$ respectively). This suggests that the majority tended to assess their overall ability in English in a relatively low level.

When asked about an English language skill and knowledge they wanted to improve the most, the majority (64.7\%) reported that they needed to improve their speaking skill the most, followed by listening skill $(20 \%)$, reading skill $(5.9 \%)$, vocabulary knowledge $(4.7 \%)$, grammar knowledge $(3.5 \%)$, and writing skill $(1.2 \%)$ respectively. Thus, it is evident that the students seemed to share the same needs in improving their speaking ability.

In terms of their opinions on the importance of English for their future profession, $72.9 \%$ of the students reported that English is very important and the rest of them (27.1\%) thought that English is important. Hence, it is clear that all students showed a positive attitude towards the importance of English for their career paths.

As for participants' views on purposes of using English, Figure 1 shows percentages of students who reported their purposes of using English in specific situations as follows.

\section{Percentage of students}

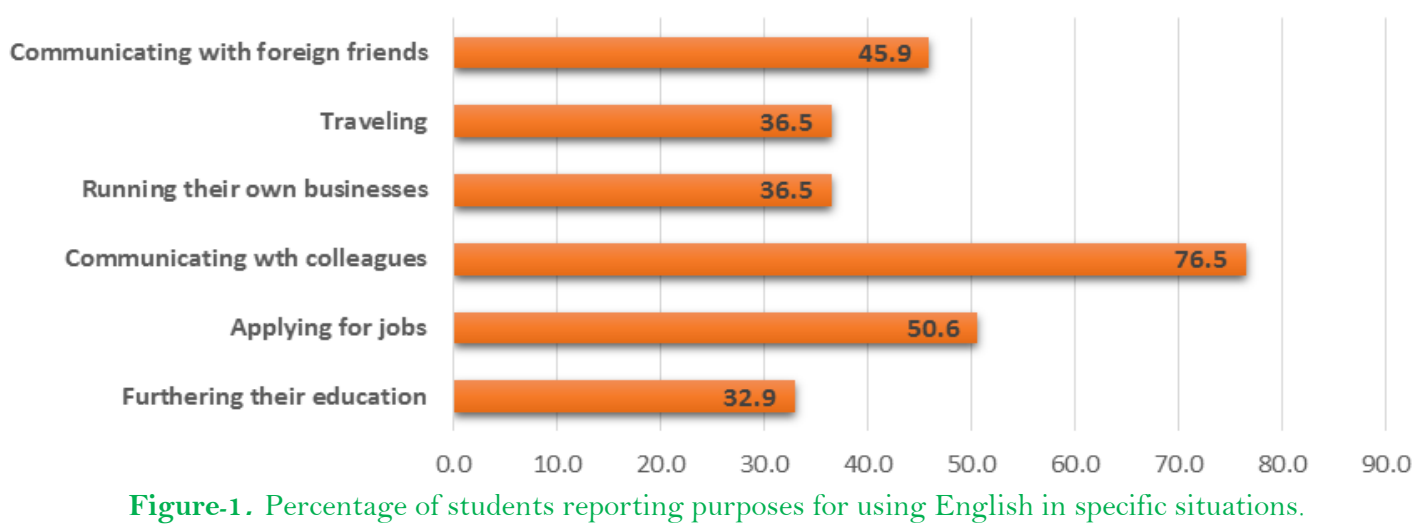

It can be seen that most of the students (76.5\%) viewed that they would use English for communicating with their future colleagues, followed by for job application (45.9\%). Therefore, the purpose of using English for these students were for work-related reasons, whereas using English for pursuing a higher degree came last (32.9\%). 
In conclusion, the majority of students evaluated their English proficiency in specific skills as fair. They also expressed their desire to improve their speaking skill the most, and considered English as important for their careers. In addition, most of them envisaged an opportunity to use English for communication at workplace with foreign friends and colleagues. It indicates that they are well aware of their current English language ability and the areas of language they wished to improve for English are viewed as important factor for their future use in both professional and personal life.

The following section reports findings on students' perceptions of course content and language skills which provides answer to research question 1 :

RQ1: What English language skills and topics do the students perceive as necessary for an ESP course for civil engineering students?

Table-1. Means of degree of students' perceived needs for language skills and topics $(\mathrm{n}=85)$.

\begin{tabular}{|c|c|c|c|}
\hline Items & $\mathbf{M}$ & SD & Degree of needs \\
\hline 1. Reading suggestions/instructions to perform certain things & 3.80 & 0.75 & Much \\
\hline 2. Reading English textbooks & 3.52 & 0.85 & Much \\
\hline 3. Reading research abstracts/proposals & 3.39 & 1.00 & Moderate \\
\hline 4. Reading manuals & 3.55 & 0.76 & Much \\
\hline 5. Reading office documents & 3.64 & 0.90 & Much \\
\hline 6. Reading proposals/details of construction projects & 4.27 & 0.75 & Much \\
\hline 7. Reading safety signs & 4.07 & 0.81 & Much \\
\hline 8. Reading research reports & 3.62 & 0.94 & Much \\
\hline 9. Writing reports/filling forms about using equipment & 3.95 & 0.79 & Much \\
\hline 10. Writing work-related emails & 3.95 & 0.89 & Much \\
\hline 11. Writing daily work reports & 3.89 & 0.91 & Much \\
\hline 12. Writing cover letters and resumes & 4.02 & 0.84 & Much \\
\hline 13. Writing abstracts of project works & 3.52 & 0.96 & Much \\
\hline 14. Delivering oral presentations on project designs & 4.13 & 0.84 & Much \\
\hline 15. Speaking in daily life situations & 3.89 & 0.85 & Much \\
\hline $\begin{array}{l}\text { 16. Speaking in professional conversations, e.g. describing your jobs, } \\
\text { coordinating and communicating with colleagues and clients }\end{array}$ & 4.25 & 0.86 & Much \\
\hline 17. Speaking in a seminar, conference, or a meeting situation & 4.07 & 0.99 & Much \\
\hline 18. Speaking in a job interview situation & 4.28 & 0.72 & Much \\
\hline 19. Listening to English-speaking boss's instruction & 4.24 & 0.67 & Much \\
\hline $\begin{array}{l}\text { 20. Listening to presentations and discussions in a meeting, seminar or } \\
\text { conference }\end{array}$ & 4.14 & 0.80 & Much \\
\hline Total & 3.91 & 0.56 & Much \\
\hline
\end{tabular}

As seen in Table 1, the overall mean of students' needs for language skills and topics listed in the questionnaire was 3.91 suggesting that those skills and topics were much needed by the students and were necessary for an ESP course for civil engineering students. The top five most preferred language skills and topics are speaking in a job interview situation followed by reading proposals/details of construction projects, speaking in professional conversations, listening to English-speaking boss's instruction, listening to presentations and discussions in a meeting, seminar or conference, respectively. This finding is consistent with Kaewpet (2009) study in that most of the top five skills, except listening to presentations and discussions in a meeting, co-occurred with communicative events that were recommended to be included in the course for civil engineering students. However, overall skills and topics that students in the present study perceived to be necessary for their ESP course were related to both study and work situations. Thus, the students required the content of the course for academic and professional purposes. The following section reports findings on students' perceptions of learning and teaching activities which provide answer to research question 2:

RQ2: What features of learning and teaching activities do the students prefer for an ESP course?

Table-2. Means of degree of students' perceptions of their preferred learning and teaching activities $(\mathrm{n}=85)$.

\begin{tabular}{l|c|c|c}
\hline Statements & M & SD & Degree of agreement \\
\hline 1. Classroom activities should be done in pairs or groups. & 4.01 & 0.73 & Agree \\
\hline 2. Classroom activities should be done individually. & 3.29 & 0.94 & Moderately agree \\
\hline 3. Out-of-class assignments be done in pairs or groups. & 3.93 & 0.78 & Agree \\
\hline 4. Out-of-class assignments be done individually only. & 2.95 & 1.07 & Moderately agree \\
\hline 5. Teachers should use only English for instruction. & 3.16 & 1.02 & Moderately agree \\
\hline 6. Teachers should use both Thai and English for instruction. & 4.19 & 0.81 & Agree \\
\hline Total & 3.59 & 0.48 & Agree \\
\hline
\end{tabular}


As seen in Table 2, the overall mean of students' perceptions (3.59) indicated that they generally agree with features of language learning and teaching activities listed in the questionnaire. However, they moderately agreed with the ideas of performing activities in class and outside class individually and using only English for instruction. Thus, it can be assumed that the students tended to feel more comfortable with doing classroom activities and outof-class assignments in pairs and group rather than individually. They also seemed to prefer teachers using both Thai and English for instruction.

\subsection{Results from the Focus Group Interview}

This section provides an account of students' perceptions on different aspects of the ESP course they had finished which were elicited by means of a focus group interview with 7 students. The findings provide answer to research question 3: what are the students' perceptions of the ESP course they had taken? The results are presented according to the following themes.

\subsection{Students' English Language Learning Experience}

With regard to students' English language learning experience, they reported that they have learned English since they were in a kindergarten level. However, they reflected that they did not like learning English partly because of their bad experience with teachers' styles of teaching, and they had not seen any improvement in teaching approaches. This can be seen from one student's comment: "the content is still the same as before and the way of teaching is still the same, so I don't really understand the lessons" (S2). S3 also stated that she preferred learning English at a tutoring school as she could learn the language through games and had more opportunities to use vocabulary in real situations, but in her classroom she did not have such opportunities due to a large class size. S6 also added that in high school, there was too much emphasis on writing skills which he did not enjoy much. However, they all agreed that their English learning experience at university is much better and more useful, especially the ESP course which they hope to use it at their potential workplace.

\subsection{The Use of English outside the Classroom}

Generally, the students used English in daily life for pleasure such as playing online games, listening to music and watching English movies. S2 said that he used English to communicate with other game players online. They also used English knowledge to read textbooks for their study. However, they did not have much experience to communicate with foreigners in their everyday life. This information might explain why most of the 85 students rated their English proficiency in every skill as fair because they lack ample exposures to the real-world situations of using English.

\subsection{Importance of English for Future Job}

All students considered English as very important for their future careers because they were well aware that English ability is required for their job application. They had been informed by the ex-civil engineering students and their lecturers that they could gain higher salary if they have a good command of English. For example, S4 said that "the graduates and my lecturers told me that English is very important for work. But right now I haven't finished the degree yet, so I don't have any clear ideas of how English will be used." However, she believed that she can use at her working sites. This awareness is consistent with students' responses to the questionnaire.

\subsection{Students' Preferred Course Content, Language Skills, and Learning and Teaching Activities}

As for students' preferred content and language skills, the students suggested that the course should provide a topic of writing resumes and filling application forms which were not taught in the previous term. English for job interview was also mentioned as "a must" for the ESP course. Writing work-related emails to communicate with suppliers and subcontractors as well as writing daily reports also mentioned by the students which is consistent with the questionnaire results that students reported to include these topics at a high degree of needs. However, the 7 students stated that they were not quite sure about how writing abstracts of project works and reading research abstracts would be useful for them. This suggests that their perceptions reported in the interview were in line with students' responses to the questionnaire in which these two topics were ranked at the bottom.

In addition, they wanted to read short texts or newspaper articles about new technology for construction or up-to-date innovations in civil engineering in order to gain new knowledge and vocabulary. They also wanted to have a list of useful basic vocabulary for civil engineering which are not too technical. This topic was not included in the questionnaire, so it is very useful information for ESP course developer to consider to include this topic the future. This shows that the students not only wanted to develop English language skills but also wanted to gain new vocabulary and up-to-date knowledge about their civil engineering world.

As for listening and speaking skills, the responses from the interview were similar to the questionnaire results in that the 7 students would like the course to focus on listening and speaking for receiving their boss' instructions and talking with co-workers and clients in both informal and formal contexts. Listening and speaking for attending workshops, seminars, and company meetings were also needed.

In terms of learning and teaching activities, the interview results also revealed similar findings to the questionnaire's results. That is, the interviewed students thought that pair and group work were still necessary as 
most of the time they had to converse with other students. However, they suggested not to have too much group work assignments as not all students really co-operated and participated. As for individual work, they thought that they could perform a task like giving presentation individually, but they were not sure whether less proficient students would be comfortable with this. For this group of interviewees, they would like more challenging speaking task in groups as they have been familiar with working in team.

Regarding language of instruction, they reported similar views as the seen in the questionnaire results that they preferred teacher to use both English and Thai.

\subsection{Students' Recommendations for Course Development}

The students suggested that listening and speaking skills should be the main focus of the course with additional basic grammar review. They also recommended having a foreign teacher as a visiting teacher so that they could have a chance to practice English in a real situation.

\section{Conclusion}

The overall findings suggest that 85 students demonstrated a high degree of needs to include language skills and topics listed in the questionnaire especially speaking in a job interview situation followed by reading proposals/details of construction projects, speaking in professional-related conversations, listening to Englishspeaking boss's instruction, listening to presentations and discussions in a meeting, seminar or conference. Besides, the students generally agreed that a combination of pair and group work for in-class activities and out-ofclass assignments were preferred rather than working individually. A mixture of Thai and English as language of instruction was also needed. Students' perceptions reported in the questionnaire seemed to relate to findings from the interview in many aspects. That is, they were well aware of their current English ability and considered English as essential for their future performance at their potential workplace. Their needs for more listening and speaking practices was also mentioned as in the questionnaire. Moreover, their reflections in the interview revealed that they would like to read more texts related to advancement and new innovations in their field in order to gain more vocabulary and knowledge of the content area in civil engineering. This suggests that the students expected the course to provide both English language skills related to the real-world work situation as well as vocabulary and specific knowledge of up-to-date information in their field of study. Therefore, it seemed that these students perceived an ESP course as a preparatory course to equip them with knowledge and English language skills necessary to perform communicative tasks in their professional life when they graduate.

\section{Implications of the Study}

Based on the past civil engineering students' perspectives, results reported in this study provides useful information for course developers to design an ESP course for civil engineering students in the upcoming academic year that corresponds to students' expectations and needs. Descriptions of desired content and specific language skills helps course developers to select appropriate topics and prioritize the sequence of those topics based on what students perceived as necessary as much as possible. Students' reflections on what is missing from the course or lacks can yield useful information for improving the course. The results can also be used as guidelines for designing a course book or supplementary materials that are deemed suitable for students in this particular context as students in different contexts may differ in their language learning needs, English language proficiency, learning styles as well as the knowledge of the world. It is recommended that ESP teachers of other fields of engineering pay more attention to identifying learners' language learning needs to fulfill students' goals in learning the course as well as to meet expected learning outcomes that their School of Engineering have identified in their curriculum. Once Thai students' needs are addressed, students might see learning English as a meaningful and purposeful endeavor and be more motivated to improve their professional English.

\section{Limitations of the Study and Suggestion for Future Research}

Firstly, given the small sample size of the third-year 85 civil engineering major students, the findings must be treated with caution as they might not be transferable to other wider contexts or might not represent perceptions of all students in other years of study. Therefore, further research should be carried out with a larger number of participants including students from all years of study in this major. This would provide a better understanding of the students' expectations of their ESP course.

Secondly, NA results of this study were based on the past students' perspectives using classroom-learning analyses strategy suggested by Brown (2016) which may not fully represent needs of other stakeholder such as ESP teachers, civil engineering lecturers, civil engineers, or professionals in civil engineering industry. Therefore, future research should collect NA data from those stakeholders to determine needs from different perspectives.

Finally, it is recommended that future research should collect more qualitative data by conducting more interviews with different groups of learners or other stakeholders to gain more in depth data which might better compliment data from questionnaires. 


\section{References}

Aliakbari, M., \& Boghayeri, M. (2014). A needs analysis approach to ESP design in Iranian context. Procedia-Social and Behavioral Sciences, 98, 175-181.Available at: https://doi.org/10.1016/j.sbspro.2014.03.404

Brown, J. D. (2016). Introducing needs analysis and english for specific purposes. London: Routledge.

Brown., J. D. (1995). The elements of language curriculum: A systemic approach to program development. Boston: Heinle and Heinle.

Byram, M., \& Hu, A. (2017). Routledge encyclopedia of language teaching and learning. London: Routledge.

Changpueng, P., \& Pattanapichet, F. (2015). An analysis of English in the workplace: The needs of engineers in writing in English. Silpakorn University Journal of Social Sciences, Humanities, and Arts, 15(3), 151-176.

Dehnad, A., Bagherzadeh, R., Bigdeli, S., Hatami, K., \& Hosseini, A. F. (2014). Post graduate ESP curriculum: Reading and writing needs. Acta Medica Iranica, 52(5), 406-410.

Dörnyei, Z. (2007). Research methods in applied linguistics. Oxford: Oxford University Press.

Flowerdew, L. (2013). Needs analysis and curriculum development. In Paltridge, B. \& Starfield, S. (Eds.), The handbook of English for Specific Purposes (pp. 325-346). Oxford: Balckwell.

Gözüyeşil, E. (2014). An analysis of engineering students' English language needs. Procedia-Social and Behavioral Sciences, 116, 41824186.Available at: https://doi.org/10.1016/j.sbspro.2014.01.913.

Hyland, K. (2006). English for specific purposes. London: Routledge.

Kaewpet, C. (2009). Communication needs of Thai civil engineering students. English for Specific Purposes, 28(4), 266-278.Available at: https://doi.org/10.1016/j.esp.2009.05.002.

Kim, H. H. (2013). Needs analysis for English for specific purpose course development for engineering students in Korea. International Journal of Multimedia and Ubiquitous Engineering, 8(6), 279-288.Available at: https://doi.org/10.14257/ijmue.2013.8.6.28.

Long, M. (2005). Methodological issues in learner needs analysis. In M. Long (Ed.), Second Language Needs Analysis (pp. 19-76). Cambridge: Cambridge University Press.

Lung, J. (2014). A blended needs analysis: Critical genre analysis and needs analysis of language and communication for professional purposes. In Vijay, B. \& Stephen, B. (Eds.), The Routledge Handbook of Language and Professional Communication (pp. 257-273). London: Routledge.

Scrivener, J. (2005). Learning teaching (2nd ed.). Oxford, UK: Macmillan Education.

West, R. (1994). Needs analysis in language teaching. Language Teaching, 27(1), 1-19. 